\title{
PENGARUH JOB INSECURITY, STRES KERJA, DAN WORK-FAMILY CONFLICT TERHADAP BURNOUT KARYAWAN DI PT LOTTE SHOPPING INDONESIA CABANG MEDAN
}

\author{
Ferdinand Jonri Nainggolan \\ Program Studi Magister Manajemen Universitas Tarumanagara \\ ferdinandjonri@gmail.com
}

Masuk : 07-12-2020, revisi : 23-12-2020, diterima untuk diterbitkan : 28-12-2020

\begin{abstract}
Human resources are an asset for a company that has a very important function for the survival of a company. At present, with the problem of the COVID-19 pandemic, employees in a company will be required to work harder because the number of employees cannot be maximized, but with the same performance demands, making employees in a company more drained. This includes some companies that run shifting systems. This is what causes burnout problems in the company, especially at PT Lotte Shopping Indonesia Medan Branch. This research was conducted to know the effect of Job Insecurity, Job Stress, and Work-Family Conflict on Employee Burnout at PT Lotte Shopping Indonesia Medan Branch. The research method used in this research is quantitative research methods. The data collection method used was a questionnaire distributed to employees at PT Lotte Shopping Indonesia Medan branch totaling 133 people. The data processing method used in this research is Partial Least Square. The results showed that job insecurity had no effect on burnout, work stress had a significant positive effect on burnout, work-family conflict had a significant positive effect on burnout.
\end{abstract}

Keywords: Job Insecurity, Work Stress, Work-Family Conflict, Burnout

\begin{abstract}
Abstrak: Sumber daya manusia merupakan aset bagi sebuah perusahaan yang memiliki fungsi sangat penting bagi kelangsungan hidup sebuah perusahaan. Saat ini, dengan adanya permasalahan mengenai pandemi COVID-19, membuat karyawan dalam sebuah perusahaan akan dituntut untuk bekerja lebih keras karena jumlah karyawan yang tidak bisa lebih maksimal, namun dengan tuntutan kinerja yang tetap sama, membuat karyawan dalam sebuah perusahaan akan lebih terkuras tenaganya, termasuk dalam hal ini bagi beberapa perusahaan yang menjalankan sistem shifting. Hal ini yang membuat adanya masalah burnout dalam perusahaan, terutama di PT Lotte Shopping Indonesia cabang Medan. Penelitian ini dijalankan dengan tujuan untuk mengetahui Pengaruh Job Insecurity, Stres Kerja, dan Work-Family Conflict terhadap Burnout Karyawan di PT Lotte Shopping Indonesia cabang Medan. Metode penelitian yang digunakan dalam penelitian ini adalah metode penelitian kuantitatif. Metode pengumpulan data yang digunakan adalah kuisioner yang disebarkan kepada karyawan pada PT Lotte Shopping Indonesia cabang Medan sejumlah 133 orang. Metode pengolahan data yang digunakan dalam penelitian ini adalah Partial Least Square. Hasil penelitian menunjukkan bahwa Job insecurity tidak berpengaruh terhadap burnout, Stres kerja berpengaruh positif signifikan terhadap burnout, Work-family conflict berpengaruh positif signifikan terhadap burnout.
\end{abstract}

Kata Kunci: Job Insecurity, Stres Kerja, Work-Family Conflict, Burnout

\section{PENDAHULUAN}

Sumber daya manusia merupakan aset bagi sebuah perusahaan yang memiliki fungsi sangat penting bagi kelangsungan hidup sebuah perusahaan. Saat ini, dengan adanya permasalahan mengenai pandemi COVID-19, membuat karyawan dalam sebuah perusahaan akan dituntut untuk bekerja lebih keras karena jumlah karyawan yang tidak bisa maksimal. 
Selain itu, pandemi COVID-19 tidak hanya menganggu kinerja karyawan saja, namun juga mengganggu psikologis karyawan karena karyawan tentunya akan merasa khawatir masa depan dan keamanan mereka. Dengan kelelahan fisik dan mental yang dirasakan, maka karyawan akan merasakan sebuah perasaan yang dinamakan burnout.

Job burnout diasumsikan sebagai kondisi kelelahan fisik, emosional, dan mental yang diakibatkan oleh komunikasi langsung dan lama dengan individu dalam kondisi sulit. Menurut Golonka et al. (2019), burnout merupakan sindrom yang digambarkan sebagai keadaan kelelahan yang dapat terjadi dalam berbagai konteks pekerjaan di mana karyawan menjadi sinis dalam kaitannya dengan pekerjaan mereka dan pengalaman menurunnya efektivitas professional

Burnout akan diteliti dari beberapa faktor yang berkaitan dengan keadaan saat ini, dimana pandemi COVID-19 akan melahirkan efek-efek tertentu bagi karyawan. Penelitian ini dilakukan di PT Lotte Shopping Indonesia cabang Medan yang saat ini terindikasi mengalami permasalahan mengenai tingkat burnout karyawan yang tinggi.

Faktor pertama yang diduga mempengaruhi burnout karyawan di PT Lotte Shopping cabang Medan adalah ketidakyakinan kerja atau job insecurity. Menurut Xiao et al. (2018), job insecurity didefinisikan sebagai "ketidakberdayaan yang dirasakan untuk mempertahankan kelangsungan yang diinginkan dalam situasi pekerjaan yang terancam”. Keterkaitan antara job insecurity terhadap burnout adalah saat seorang karyawan, di masa pandemi COVID-19 ini merasakan bahwa mereka tidak bisa selalu merasa aman dengan jabatan atau posisi mereka di perusahaan.

Faktor kedua yang diduga mempengaruhi burnout karyawan di PT Lotte Shopping Indonesia cabang Medan adalah stres kerja. Menurut Gharib et al. (2016), stres kerja adalah status yang terjadi ketika individu menyadari bahwa kondisi atau ketegangan yang dihadapi mereka mungkin lebih dari daya tahan mereka. Keterkaitan antara stres kerja dengan burnout adalah saat seorang karyawan merasakan tingkat stres yang tinggi, karyawan tersebut cenderung tidak akan fokus dalam bekerja karena merasa adanya tekanan dalam diri mereka. Ditambah dengan adanya pandemi COVID-19 saat ini, tentunya akan membuat tingkat stres kerja karyawan semakin tinggi.

Faktor lainnya yang diteliti adalah work-family conflict. Menurut He et al. (2019), workfamily conflict merupakan salah satu bentuk konflik antar peran yang disebabkan oleh ketidaksesuaian pekerjaan dan tuntutan keluarga. Intinya, partisipasi dalam peran pekerjaan (keluarga) menjadi lebih sulit dengan berpartisipasi dalam peran keluarga (pekerjaan). Workfamily conflict yang tinggi dapat meningkatkan tingkat burnout karyawan di perusahaan.

Melalui penelitian terdahulu yang sudah dilakukan serta observasi yang telah dijalankan, maka penelitian ini akan meneliti pengaruh Job Insecurity, Stres Kerja dan Work-Family Conflict terhadap Burnout karyawan di PT Lotte Shopping Indonesia cabang Medan.

\section{Tujuan Penelitian}

Tujuan dari penelitian ini adalah sebagai berikut:

1. Untuk mengetahui pengaruh Job Insecurity terhadap Burnout pada PT Lotte Shopping Indonesia cabang Medan.

2. Untuk mengetahui pengaruh Stres Kerja terhadap Burnout pada PT Lotte Shopping Indonesia cabang Medan.

3. Untuk mengetahui pengaruh Work-Family Conflict terhadap Burnout pada PT Lotte Shopping Indonesia cabang Medan.

\section{TINJAUAN PUSTAKA}

Burnout

Menurut Bazmi et al. (2019), job burnout diperkenalkan pada tahun 1970 sebagai pola pikir negatif terkait pekerjaan yang terjadi karena adanya tuntutan pekerjaan seperti kelebihan beban kerja, jam kerja yang berkepanjangan, kurangnya keadilan, konflik pekerjaan, 
kurangnya dukungan sosial dari rekan kerja atau supervisor, dan kurangnya otoritas pengambilan keputusan.

\section{Job Insecurity}

Menurut Richter et al. (2010), job insecurity memiliki efek negatif yang terdokumentasi dengan baik bagi individu maupun organisasi. Job insecurity tampaknya terkait dengan reaksi negatif individu. Hal tersebut dapat menimbulkan dampak negatif baik terhadap individu, kelompok maupun organisasi itu sendiri. Berfokus pada kesejahteraan karyawan, ketidakamanan kerja dikatakan dapat mengurangi atau menyebabkan kesejahteraan karyawan memburuk.

\section{Stres Kerja}

Stres kerja merupakan respon seseorang baik berupa emosi fisik, kognitif (konseptual) terhadap situasi yang memerlukan tuntutan tertentu pada individu. Karyawan dalam keadaan tegang yang menyebabkan ketidakseimbangan fisik dan psikis yang mempengaruhi emosi dan berpikir (Rivai, 2014).

\section{Work-Family Conflict}

Greenhaus dan Beutell (1985) dalam Kebriaei et al. (2016) menjelaskan bahwa konflik pekerjaan-keluarga terjadi ketika (a) waktu yang dicurahkan untuk persyaratan satu peran membuat sulit untuk memenuhi persyaratan yang lain; (b) tekanan dari partisipasi dalam satu peran mempersulit pemenuhan persyaratan peran lainnya; dan (c) perilaku khusus yang dibutuhkan oleh satu peran membuatnya sulit untuk memenuhi persyaratan peran lainnya.

\section{METODOLOGI PENELITIAN}

Desain pada penelitian ini dirancang menggunakan jenis penelitian kuantitatif dengan pendekatan kausal. Dalam penelitain ini, pengambilan data dilakukan dengan menyebarkan kuisioner secara langsung kepada sumber nya yaitu karyawan pada PT Lotte Shopping Indonesia cabang Medan sejumlah 133 orang. Dalam penelitian ini untuk menghitung jumlah sampel digunakan rumus Slovin sebagai berikut:

\section{Dimana:}

$$
\mathrm{n}=\frac{\mathrm{N}}{1+\mathrm{Ne}^{2}}
$$

$$
\begin{aligned}
\mathrm{n}= & \text { jumlah sampel } \\
\mathrm{N}= & \text { jumlah populasi } \\
\mathrm{e}= & \text { presisi atau peran kelonggaran ketidaktelitian karena kesalahan pengambilan sampel } \\
& \text { yang masih dapat ditolerir atau diinginkan, yaitu sebesar } 5 \% \text { atau } 0,05 \text { (Riduwan, } \\
& \text { 2004, p. } 65 \text { ). }
\end{aligned}
$$

Berdasarkan rumus Slovin di atas, maka jumlah sampel yang diambil dalam penelitian ini sebesar:

$$
\begin{aligned}
& \mathrm{N}=131 \\
& \mathrm{e}=10 \%
\end{aligned}
$$

$\mathrm{n}=99$

$$
\mathrm{n}=\frac{131}{1+131(0,05)^{2}}
$$

Dalam penelitian ini, metode pengolahan data yang digunakan adalah regresi dengan Partial Least Square. Regresi Partial Least Square merupakan sebuah metode pengujian dimana pada dasarnya memiliki konsep serupa dengan pengujian regresi parametrik, namun perbedaan antara regresi Partial Least Square dengan regresi sederhana maupun berganda adalah kemampuan dari Partial Least Square dalam mengukur korelasi antara variabel terhadap masing-masing indikator, sehingga regresi dengan Partial Least Square cenderung lebih akurat untuk menunjukkan hasil penelitian. 


\section{HASIL DAN KESIMPULAN}

Penelitian ini menggunakan Discriminant validity yang dilakukan didalam dua tahap, yaitu dengan cara melihat nilai cross loading factor serta membandingkan akar AVE (Average Variance Extracted) dengan korelasi diantar konstruk/variabel laten. Cross loading factor agar dapat mengetahui apakah variabel laten mempunyai diskriminan yang memadai yaitu dengan cara membandingkan korelasi indikator terhadap variabel latennya harus lebih besar dibandingkan korelasi diantara indikator dengan variabel laten yang lain. kalau korelasi indikator dengan variabel latennya memiliki nilai lebih tinggi terhadap korelasi indikator tersebut terhadap variabel laten lain, maka dikatakan variabel laten itu memiliki validitas diskriminan yang tinggi.

Hasil pengujian hipotesis yang telah dilakukan dalam penelitian ini untuk dapat menentukan apakah hipotesis yang telah dibuat dalam penelitian ini mempunyai pengaruh yang siginifikan. Hasil dalam penelitian ini terbukti bahwa seluruh variabel independen berpengaruh signifikan terhadap variabel dependen. Pengujian hipotesis penelitian ini dilihat dari nilai tstatistik atau p-values. Berikut hasil dari nilai t-statistik dan p-values yang akan ditampilkan dalam tabel berikut:

Tabel 1

Hasil Pengujian Hipotesis

\begin{tabular}{|c|c|c|c|}
\hline & Original Sample & T Statistics & P Values \\
\hline Job Insecurity $\rightarrow$ Burnout & 0.243 & 1.774 & 0.077 \\
\hline Stres Kerja $\rightarrow$ Burnout & 0.376 & 3.159 & 0.002 \\
\hline Work-Family Conflict $\rightarrow$ Burnout & 0.354 & 3.861 & 0.000 \\
\hline
\end{tabular}

Uji hipotesis pada penelitian ini dilakukan dengan melihat nilai $t$-statistics dan nilai $p$ values. Hipotesis penelitian dapat dinyatakan diterima apabila nilai nilai t-statistik lebih besar dari 1,96 dan nilai $p$-values $<0,05$. Berikut ini adalah hasil uji hipotesis yang diperoleh dalam penelitian ini:

H1: Job Insecurity berpengaruh terhadap Burnout pada PT Lotte Shopping Indonesia cabang Medan

H2: Stres Kerja berpengaruh terhadap Burnout pada PT Lotte Shopping Indonesia cabang Medan

H3: Work-Family Conflict berpengaruh terhadap Burnout pada PT Lotte Shopping Indonesia cabang Medan

\section{Kesimpulan}

Berdasarkan hasil analisis dan pengolahan yang telah dijalankan pada penelitian berjudul

Pengaruh Job Insecurity, Stres Kerja, dan Work-Family Conflict terhadap Burnout Karyawan di PT Lotte Shopping Indonesia Cabang Medan, maka dapat dijabarkan beberapa kesimpulan sebagai berikut:

1. Job Insecurity tidak berpengaruh terhadap Burnout pada PT Lotte Shopping Indonesia cabang Medan. Hal ini menunjukkan bahwa memang ketidakpastian kerja belum menjadi prediktor yang dapat membentuk kelelahan fisik dan mental karyawan di perusahaan.

2. Stres Kerja berpengaruh positif signifikan terhadap Burnout pada PT Lotte Shopping Indonesia cabang Medan. Keterkaitan antara Stres Kerja dengan Burnout adalah saat seorang karyawan merasakan tingkat stres yang tinggi, karyawan tersebut cenderung tidak akan fokus dalam bekerja karena merasa adanya tekanan dalam diri mereka. Ditambah dengan adanya pandemi COVID-19 saat ini, tentunya akan membuat tingkat stres kerja karyawan semakin tinggi karena dilanda dengan suatu hal yang dapat membahayakan diri mereka. Dengan stres yang tinggi, membuat karyawan akan terkuras secara mental dan fisik karena mereka harus bekerja lebih berat dan membuat karyawan merasa kelelahan.

3. Work-Family Conflict berpengaruh positif signifikan terhadap Burnout pada PT Lotte Shopping Indonesia cabang Medan. Hal ini terjadi karena saat karyawan merasakan adanya konflik antara kepentingan untuk menjaga hubungan mereka dengan keluarga 
dengan kepentingan mereka untuk mempertahankan kinerja kerja di tempat kerja akan membuat lama kelamaan karyawan merasa lelah secara mental dan akan membuat karyawan merasakan burnout.

\section{DAFTAR PUSTAKA}

Bazmi, E., Alipour, A., Yasamy, M. T., Kheradmand, A., Salehpour, S., Khodakarim, S., \& Soori, H. (2019). Job burnout and related factors among health sector employees.

Iranian Journal of Psychiatry, 14(4), 309-316. https://doi.org/10.18502/ijps.v14i4.1982

Gharib, M. N., Jamil, S. A., Ahmad, M., \& Ghouse, S. (2016). The impact of job stress on job performance: A case study on academic staff at dhofar university. International Journal of Economic Research, 13(1), 21-33.

Golonka, K., Mojsa-Kaja, J., Blukacz, M., Gawłowska, M., \& Marek, T. (2019). Occupational burnout and its overlapping effect with depression and anxiety. International Journal of Occupational Medicine and Environmental Health, 32(2), 229244. https://doi.org/10.13075/ijomeh.1896.01323

Greenhaus, J. H., \& Beutell, N. J. (1985). Sources of conflict between work and family roles. The Academy of Management Review, 10(1), 76. https://doi.org/10.2307/258214

He, G., An, R., \& Zhang, F. (2019). Cultural intelligence and work-family conflict: A moderated mediation model based on conservation of resources theory. International Journal of Environmental Research and Public Health, 16(13). https://doi.org/10.3390/ijerph16132406

Kebriaei, A., Abedizadeh, F., \& Sharifian, T. (2016). Study on the conflicts between work and family at the Kashan University of Medical Sciences, Iran. International Letters of Social and Humanistic Sciences, 74, 48-53. https://doi.org/10.18052/www.scipress.com/ilshs.74.48

Richter, A., Näswall, K., \& Sverke, M. (2010). Job insecurity and its relation to work-family conflict: Mediation with a longitudinal data set. Economic and Industrial Democracy, 31(2), 265-280. https://doi.org/10.1177/0143831X09358370

Riduwan. (2004). Metode riset. Rineka Cipta.

Rivai, V. (2014). Manajemen sumber daya manusia untuk perusahaan (6th ed.). PT Raja Grafinfo Persada.

Xiao, Z., Wu, D., \& Liao, Z. (2018). Job insecurity and workplace deviance: The moderating role of locus of control. Social Behavior and Personality, 46(10), 1673-1686. https://doi.org/10.2224/sbp.7160 